\title{
Covid19 and cancer care: the end of the beginning
}

\author{
Robert Kratzke \\ Department of Medicine, University of Minnesota Medical School, Minneapolis, MN 55455, USA. \\ Correspondence to: Prof. Robert Kratzke, Department of Medicine, University of Minnesota Medical School, MMC 480, 420 \\ Delaware St, SE Minneapolis, MN 55455, USA. E-mail: kratz003@umn.edu \\ How to cite this article: Kratzke R. Covid19 and cancer care: the end of the beginning. J Cancer Metastasis Treat 2021;7:50. \\ https://dx.doi.org/10.20517/2394-4722.2021.146
}

Received: 8 Jul 2021 Accepted: 13 Jul 2021 First online: 14 Jul 2021

Academic Editor: Lucio Miele Copy Editor: Xi-Jun Chen Production Editor: Xi-Jun Chen

The spread of COVID19 across the globe has caused unspeakable grief and suffering for millions. It has also impacted the care and outcomes for our cancer patients. As of July 2021, nearly 4 million deaths worldwide have been attributed to Covid19. Thankfully, according to data from the Johns Hopkins University Coronavirus Resource Center website ${ }^{[1]}$, almost 4 million doses of vaccine have also been administered worldwide. There have been numerous challenges for those who take care of cancer patients over the last 18 months related to Covid19. These range from patients delaying visits for critical cancer care to disruptions of supply chains resulting in the absence of crucial medicines.

Going forward, difficulties will remain as disparities in vaccine supplies continue to impact communities around the world. In addition, chronic symptoms of dyspnea and fatigue plague many survivors of Covid 19. These "long haulers" will face continued challenges as they battle existing and future cancer diagnoses ${ }^{[2]}$. Those of us who practice cancer medicine may expect to see more survivors of Covid 19 with compromised lung function and chronically poor performance status in the coming years. Also, without a doubt, Covid19 will continue to exist as potential comorbidity for our patients in the future. New diagnoses and outbreaks can be expected to arise as variants develop that may prove more virulent or even resistant to our current vaccines. How oncology practices deal with these ongoing issues will be a defining moment for the current generation of cancer caregivers worldwide. 
However, there are also great lessons to be learned from this experience. Certainly, virtual visits have proven to enhance access to cancer care in remote regions in much of the technologically advanced world. Although we must guard against virtual visits replacing the importance of face-to-face meetings, including physical examination, virtual visits can allow patients to potentially receive important cancer care close to their home while still accessing high-quality expert advice from an oncologist located hours away.

In addition, the spectacular and rapid development of vaccines using novel mRNA technologies has opened a whole new view of cancer therapies as well. Although dedicated teams of investigators have been exploring therapies based on native or modified RNA transcripts for several decades, we are now witnessing the fruits of those efforts ${ }^{[3]}$. There is every reason to believe that this technology, which has now proven itself in during the Covid19 epidemic, will prove helpful in the future in delivering targeted proteins and peptides via mRNA technology to cancers ${ }^{[4,5]}$.

In this issue, the authors address some of these issues. The battle with Covid19 is far from over or even won. However, as oncologists, we should appreciate more than many others that the battle for control over a disease is often long and filled with disappointments. Nonetheless, as we are already seeing, constant effort and scientific inquiry should lead us to not only control this coronavirus but improve cancer care for our patients.

\section{DECLARATIONS}

\section{Authors' contributions}

The author contributed solely to the article.

\section{Availability of data and materials}

Not applicable.

\section{Financial support and sponsorship}

None.

\section{Conflicts of interest}

The author declared that there are no conflicts of interest.

\section{Ethical approval and consent to participate}

Not applicable.

\section{Consent for publication}

Not applicable.

\section{Copyright}

(c) The Author(s) 2021.

\section{REFERENCES}

1. John Hopkins Coronavirus Resource Center. Johns Hopkins University \& Medicine. Available from: https://coronavirus.jhu.edu/us-map . [Last accessed on 20 Jul 2021].

2. Nalbandian A, Sehgal K, Gupta A, et al. Post-acute COVID-19 syndrome. Nat Med 2021;27:601-15. DOI PubMed

3. Shin MD, Shukla S, Chung YH, et al. COVID-19 vaccine development and a potential nanomaterial path forward. Nat Nanotechnol 2020;15:646-55. DOI PubMed

4. Copur M. Messenger RNA vaccines: beckoning of a New Era in cancer immunotherapy. Oncology (Williston Park) 2021;35:190-8. DOI PubMed

5. McNamara MA, Nair SK, Holl EK. RNA-based vaccines in cancer immunotherapy. J Immunol Res 2015;2015:794528. DOI PubMed PMC 